NBER WORKING PAPER SERIES

EMPLOYER BEHAVIOR IN THE FACE OF UNION ORGANIZING DRIVES

Richard B, Freeman

Morris M. Kleiner

Working Paper No. 2805

NATIONAL BUREAU OF ECONOMIC RESEARCH

1050 Massachusetts Avenue

Cambridge, MA 02138

December 1988

This study was funded by the National Science Foundation. The authors want to thank William Dickens, and participants in seminars at Bradley University, NBER, and the University of Minnesota for many helpful comments. We also want to thank Janet Bull, Alida Castillo-Freeman, and Thomas Clifton for their research assistance. This research is part of NBER's research program in Labor Studies. Any opinions expressed are those of the authors not those of the National Bureau of Economic Research. 
NBER Working Paper \#2805

December 1988

\section{EMPLOYER BEHAVIOR IN THE FACE OF UNION ORGANIZING DRIVES}

\section{ABSTRACT}

The direct role of employers in union organizing has long been a neglected part of the union organizing literature. In this study we examine the determinants and consequences of employer behavior when faced with an organizing drive. Our principal substantive findings are:

- that there is a substitution between high wages/benefits/good work conditions/supervisory practices and "tough" management opposition to unionism.

- that a high innate propensity for a union victory deters management opposition, while some indicators of a low propensity also reduce opposition.

- that "positive industrial relations" raise the chances the firm will defeat the union in an election, as does bringing in consultants and having supervisors campaign intensely against the union.

- that the careers of managers whose wages/supervisory practices/ benefits lead to union organizing drives, much less to union victories, suffer as a result.

In general we interpret our results as consistent with the notion that firms behave in a profit maximizing manner in opposing an organizing drive and with the basic proposition that management opposition, reflected in diverse forms of behavior, is a key component in the on-going decline in private sector unionism in the United States.

Richard B. Freeman

National Bureau of Economic Research 1050 Massachusetts Avenue Cambridge, MA 02138
Morris M. Kleiner Humphrey Institute 231 Humphrey Center 30119 th Avenue, S. University of Minnesota Minneapolis, MN 55455 
The behavior of management toward trade unionism has changed greatly in the United States in the past quarter century. In the 1960 s management at most large firms recognized unions as a permanent labor market institution and viewed collective bargaining as an acceptable mode for determining wages and working conditions. They sought the best deals they could get through the bargaining process and worried that unions had acquired too much economic power in society. 1 In the 1970 s and 1980 s management's attitude and behavior changed dramatically. ${ }^{2}$ The goal of a union-free environment, once espoused by fringes of the management community, spread until by 1983 45 of the relatively progressive firms in the BNA's Personnel Practices Forum declared that being nonunion was their major labor relations goal (Kochan, McKersie and Chalykoff, 1986). Unfair labor practices committed by management skyrocketed despite a decline in NLRB representation elections. and approximately one-third of the firms whose workers voted to unionize remained nonunion by failing to sign a collective contract, effectively reversing the result of the election. ${ }^{3}$ Management opposition, of one form or another, has been found to be a key determinant of NLRB elections (Dickens, 1983; Freeman, 1988), and many have come to believe that the growth of opposition has been a major, if not the major, direct cause of the decline in private sector unionism in the U.S. (Freeman and Medoff. 1984; Dickens and Leonard, 1985; Farber, 1987).

Despite the importance of management opposition in de-unionizing the private sector (where density fell from 318 in 1967 to 138 in 1987 using Current Population Survey estimates) relatively little is known about what determines the extent and method of opposition to unionism during an organizing drive. Is the nature and depth of management opposition the 
result of differences in the likely costs of unionism to the firm? Are higher wages and good working conditions--so-called positive industrial relations--substitutes or complements for hiring consultants, committing unfair practices, or otherwise canpaigning intensely and using expensive methods of opposition against unions during an organizing drive? What management tactic appears to have the greatest impact on outcomes?

In this paper we use two data sets gathered during 1980 s organizing drives to examine these questions. The first set is based on a survey of 202 establishments that had NLRB representation elections in the Boston and Kansas City NLRB districts. The survey obtained information from managers about the use of consultants in the election drive, perceived causes of the drive, the wages and benefits paid to workers, and the impact of union victories on the careers of the managers; and information from the NLRB about unfair labor practices and election outcomes. The second data set was obtained from a 1982-83 AFL-CIO survey of union organizers in 274 election drives. The organizers survey contains data on benefits available at the firm (but not on wages), characteristics of workers, management anti-union tactics, and organizers' perceptions of important campaign issues. Both data sets have weaknesses, because they lack information on certain aspects of campaigns and in part because they are obtained from persons with definite biases. It is for this reason that we examine them together, hopefully obtaining a more complete and accurace picture of management opposition than is possible with each set separately.

Our results reveal some substitution between "positive industrial relations" and other management tactics that may be seen as directed towards opposition to unions, with firms that have higher wages and better benefits 
or work conditions less likely to comit unfair labor practices than firms with lower wages/worse benefits or conditions. In our firm data set we find that companies that brought in consultants were more likely to defeat unions than other firms, and, perhaps most strikingly, that managers whose establishments face organizing drives are likely to suffer in their careers. In our organizers data set, we find that firms with poor work conditions/supervisory problems are especially likely to commit unfair practices while those that face a workforce with an especially high propensity to organize, as reflected, in the percentage who sign authorization cards for the election, are less likely to comit unfair practices. The most effective "hardnosed" company tactic is to have direct supervisors campaign intensely against the union. In neither data set do we find that committing unfair practices reduces the union's likelihood of winning, in part, we surmise, because of the endogeneity of the practices; that is, firms that are more likely to lose are more likely to commit an unfair labor practice, and the tendency for unions to file charges after losing elections. The remainder of the paper presents the arguments and evidence for these claims.

\section{Theory of Management Opposition}

How does management react to a union organizing drive at a particular locality? What influences the specific types of policies is it likely to adopt once it knows it is headed for an NLRB election? In this section we postulate that the reaction to an organizing drive will depend on three factors: the probability that the union will win the ensuing election and obtain a contract, and the expected impact of management opposition on that probability; the costs of opposition; and the prospective loss of profits 
due to unionization, which itself depends on the likely union wage impact. The model predicts an inverse $U$-shaped curve relating management opposition to the probability of a union win; a negative relation between "positive industrial relations" (high wages, benefits, good working condicions) and opposition; greater impacts on election outcomes for more expensive forms of opposition; and highlights the problem of evaluating what opposition does to outcomes when opposition is endogenous.

We assume at the outset that principal-agent issues between management and shareholders are of negligible importance and thus that management's actions are determined by perceptions of what unionization will do to expected profits. This is not an innocuous assumption. Union-induced changes in shareholder returns are unlikely to affect significantly the economic position of most managers, particularly the lower-level foreman and other supervisors whose behavior is critical to any management campaign to defeat unions. We assume, and later provide evidence consistent with our assumption, that firms' managerial personnel policy substitutes for the incentive of ownership. Conversely, lower-level management may devote resources to oppose unions when it is not in the shareholder's interest, sacrificing profits for control and greater flexibility at the work place. Further, as some union corporate campaigns make clear, it is possible to pressure shareholders or management into neutrality in representation elections, possibly at the expense of profits, by imbedding the issue of the union drive into a broader problem of, for example, obtaining assets from a major financial institution (Pruitt, Wei, and white, 1988).

For simpicity, we also ignore potential strategic game theoretic interactions between management opposition and union organizing efforts 
(e.g., management drives to oppose unions in one plant to send a message to unions about other plants; management decisions that depend on potential responses by the union organizing committee to target a company within a geographic area).

In simplest form our model contains three basic equations:

(1) Probability of a union victory in the campaign: P(X,MO) with $P^{\prime}=$ $\mathrm{P} / \mathrm{MO}<0$, with MO - management opposition and X - other factors that determine worker propensity to support a union, such as the composition of the work force, special conditions in the firm, and so on. Because $P$ is bounded between 0 and 1 we postulate a logistic form, with $P^{\prime}--B(1-P)(P)$ where $B$ is the impact parameter of $M O$ in the logistic equation.

(2) Cost of opposition: $C(M O)$ with $C^{\prime}>0$, where we include as opposition such actions as: committing unfalr labor practices; hiring specialized consultants to direct an anti-union campaign; directing supervisors to devote time and effort to convince workers to oppose the union, etc.

(3) Loss of profits due to unionization: L(WD) with $L^{\prime}>0$, where WD measures the likely wage (or cost) difference between the firm when it is union and when it is not.

We assume that the firm seeks to minimize the expected loss from unionization, subject to the cost and probability functions. The solution yields an inverted U-shaped relation between the extent of opposition and what we will call the innate probability of a union victory, $P(X, 0),--$ the probability the union wins absent any management opposition. The simplest way to see the inverted $U$ is to consider the decision whether or not to oppose an organizing drive. If the firm does not oppose the drive it has an expected loss of $\mathrm{L} P(X, 0)$. If it opposes the drive and chooses the optimum 
level of opposition MO* with cost $C *$, it has an expected loss of $C^{*}+L P(X$, MO*)--the sum of $(L+C *) P(X, M O *)$, the probability weighted loss if it fails to defeat the organizing drive and $[1-P(X, M O *)] C *$, the probability weighted loss if it succeeds in defeating the drive. Given these costs the firm will oppose the union drive if the expected savings from opposition exceed the cost of the management campaign:

(4) - L DP $>C *$, where $D P-P(X, M O *)-P(X, 0)$, or, letting $d P$ approximate the change in probability, $B(1-\mathrm{P}) \mathrm{P}>\mathrm{C} \star \mathrm{L}$.

Because the derivative of the logistic (or any similarly shaped probability function like the normal) varies with the level of probability, (4) implies a nonlinear relation between company opposition and the (innate) probability of a union victory: when $P$ is large and the union near certain to win, the firm will forego campaigning against the union; similarly when $P$ is small, the firm will forego campaigning as it does not have to worry seriously about a union victory. Only when there is serious doubt about the likely victor will management work hard to oppose the union.

Turning to the optimum level of management opposition, the interior solution requires that the firm equate the marginal expected benefit of opposition and the marginal cost of opposition:

(5) $P^{\prime} L-B P(1-P) L=C^{\prime}$

Since $P^{\prime}$ depends on $P(1-P)$, we again get a predicted nonlinear relation between the "innate" probability of a union win and management opposition. The closer $P$ is to one-half, the greater is the marginal benefit from opposition, and thus the greater the likely opposition.

Solving the model for management opposition yields the basic equation of concern in this study--the relation between management opposition and the 
likely union-induced loss in profits, the innate probability the union will win the election (in a nonlinear manner), and the costs of opposition:

(6) MO $-F(L, P(X, 0), C)$, where $d F / d L>0, d F / d C<0$, and where dF/dP rises and then falls with the level of P. As all of the explanatory variables in (6) are exogenous the equation can be estimated by singleequation methods.

The endogeneity of management opposition creates problems, however, in estimating the other key relation in the model, the structural impact of opposition on outcomes [equation (1)]. Unless the factors that determine the innate probability of a union win are perfectly specified, singleequation estimates of $P(X, M O)$ will be biased, presumptively toward 0 . Consider, for example, the extreme case when we have no information on $P(X, 0)$. If the probability of a union win is innately high, we will observe little opposition, and incorrectly infer: that the lack of opposition caused the win. By the nonlinearity of the opposition equation, however, we get the opposite effect when the probability of a union win is innately low: a union loss associated with lack of opposition, that could lead to the incorrect inference that lack of opposition caused the loss. The net of these effects is that single equation estimates are likely to be biased toward zero. In principle one can use $L$ and $C$ to instrument for opposition, but the available measures are too weak, at least in our data, for instrumenting to be satisfactory.

Finally, note that our data are limited to firms that face organizing drives that proceed to an NLRB conducted election. We do not deal with management opposition that deters unions from a drive or from carrying it to an election nor with management recognition of a union without a 
representation election. The absence of data on these cases further suggests that our estimates will understate the impact of opposition on a union win for the broader sample of all firms that potentially face a drive. Survey Data on Management Opposition

As noted at the outset our empirical analysis treats an employers data set and a union organizers data set. The employers data set is based on interviews with firms in the Boston and Kansas City National Labor Relations Board districts that had elections during the 1980s. We contacted 243 firms that had elections with over 20 employees in the potential bargaining unit and obtained on-site interviews with management in 202 , for a response rate of 83.1 percent: 100 were in the Boston region and 102 were in the Kansas City region; 5 percent had elections in 1985; 31 percent in 1984; 12 percent in 1983; 10 percent in 1982; 16 percent in 1981; 16 percent in 1980 and 10 percent in 1979. The states covered by the two districts are generally reflective of the national labor relations environment, ${ }^{4}$ and the win rate of unions in our sample was similar to the national average: unions won 39 percent of the elections in our sample compared to a 38 percent win rate for all elections conducted in 1981 with over 20 employees (Medoff, 1984). In addition, the proportion of firms who lost elections and signed collective contracts was close to the national average: 64 percent of the elections won by unions in our sample produced signed collective contracts; this compares with the 63 percent for the period 1979-82 (McDonald, 1983).

Our second data set is based on an AFL-CIO Department of Organization \& Field Services survey of the organizers involved in 274 NLRB election drives. The sample covers 15 AFL-CIO affiliates and consists almost entirely of units with at least 50 eligible voters. The sample is 
geographically dispersed, with observations from all regions of the country, including the South. Because some questions were added midway in the study, however, data on some aspects of management opposition are available for only half or so of the sample.

Both data sets suffer from problems of missing information for occasionally significant numbers of observations. To maximize the usable sample sizes in statistical analysis, we assigned the mean value of a variable to missing independent variables, and added a dummy variable that took the value one for that observation/variable (Little and Rubin, 1987). We report results for samples limited solely by missing observations on independent variables; however, our analysis of smaller samples limited to observations for which no independent variables were missing yield comparable results, suggesting that there is no selectivity bias with respect to observations for which there are missing values.

Table 1 summarizes the information from the surveys on the methods firms use to oppose union organizing drives. Panel A shows the frequency of use of consultants and of filed and upheld unfair labor practice charges in the employer survey. Panel B records similar information for the organizers' survey and additional information on the specific tactics used by the companies to deter unionization. Because the organizers survey included lawyers with consultants its $70 \%$ figure is much higher and we believe less accurate than the 41 s estimated usage of consultants in the employers survey. 5 The proportion of campaigns in which unions charged or could reasonably be inferred to charge unfair labor practices are of comparable magnitude between the surveys, ${ }^{6}$ though the organizers report many more discharges and discriminatory layoffs than indicated in filed charges. 
Finally, with respect to specific tactics, the organizers survey shows that the vast majority of firms used everything from leaflets to captive audience speeches to numerous small worker meetings with supervisors to oppose unionization of their work force. Approximately half of the organizers were asked to evaluate the intensity of the supervisor's efforts to oppose unions, and of those half rated the intensity as high. ${ }^{7}$

Table 2 provides some information on the issues that managers and the organizers saw as important in the organizing drive/campaign. ${ }^{8}$ The figures reveal a striking difference in their perceptions. While managers recognize that treatment of workers involving fairness or communication or dissatisfaction are important causes of union campaigns, they see purely economic issues--wages and benefits and job security--as the key factor; and also look outside their firm to union organizers or pressures from outside unions for the impetus to the drive. The organizers, by contrast, viewed supervision as by far the most important issue in the drive, with wages and fringes next in importance, and viewed the risk of strikes, the danger of layoffs or closing, and union dues as the 'most important company issues'; that is, ones that the company presented to discourage employees from voting for the union with wages of much lesser import. Finally, going beyond Table 2 , organizers reported that $23 \%$ of the drives were initiated as a result of the organizer or the international targeting the firm, which is of comparable magnitude to the percentage of firms citing union pressure as a primary cause. However, 57 of of campaigns began as a result of workers in the firm calling the union. Overall the biggest difference between the managers and organizers is in the weight placed on wages and benefits as opposed to worker-management relations or "voice" issues. 


\section{Determinants of Opposition}

The results of our analysis of the factors that determine management opposition in the employers survey are given in table 3 . Here we measure opposition with two sets of related variables: 0-1 dummy variables for whether there were unfair labor practice charges associated with the election and whether there were charges that the NLRB upheld; a 0-1 dummy for whether or not the firm hired a consultant and a continuous variable measuring the number of days the firm used the consultant. We estimated the equations with $0-1$ variables with a logistic form and used a Tobit analysis to estimate the equation for the number of consultant days used by the firm. The key dependent variable in the analysis is a measure of the likely loss of profits due to unionization: the difference between the log of hourly wages and estimated total fringes in unionized firms in the one-digit industry and occupation in its geographic area and the log of the firm's own hourly wages and fringe benefits. The greater the compensation difference the greater wage increases are likely given unionization and thus the greater the loss in profits. The estimated impact of the compensation difference variable is recorded in the first 1 ine of the table. We also examined the impact of an index of personnel practices (defined as the sum of 0-1 dummy variables for whether or not a firm had each of the five practices listed in the table note) on managerial opposition. Because the employer's survey lacks good information on the innate probability of a union victory we are unable to test for the impact of that variable on opposition. Finally, as can be seen in the table, we controlled for various other porential differences between firms, such as size of employment, occupation of workers, area, industry, and experience with unions. 
The principle finding in the cable is that firms who fall behind local area wages have a higher likelihood of committing unfair labor practices, but no greater probability of using a consultant. This is consistent with the substitution between likely profit loss and management opposition predicted by equation (6). ${ }^{9}$ The index of personnel practices, by contrast, has no clear impact on management opposition, lowering modestly the probability of committing an unfair practice that is upheld by the NLRB, but raising modestly employment of consultants. While we do not know if the firms with higher wages in our sample consciously set wages to reduce the attractiveness of unions to their workers, there is some evidence from their ensuing behavior consistent with this notion: firms with large union wage differences raised wages more than other firms after the organizing drive. 10 In sum, the employers survey data suggest a substitution between higher wages and the use of some forms of management opposition. The results suggest that firms that pay more have a reduced incentive to commit unfair practices.

The evidence on the determinants of management opposition in the organizers survey, summarized in table 4 , both supports and adds to this finding. For this portion of the analysis, we employ three measures of management opposition: charges of unfair labor practices, whether the organizer claimed union supporters were fired or discriminatorily laid off, and whether supervisors campaigned against the union. As the organizers survey lacks information on wages, 11 we measure whether an employer is practicing "positive industrial relations" and the likely profit loss by unionization by two indices: an index of the fringe benefits provided by the firm and an index of work conditions/supervisory practices. The fringe 
index counts the number of fringes provided by the firm from the list given in the table note. The work conditions/supervisory practices variable sums ratings of various conditions/practices using a $1-5$ scale, with the highest ratings indicating worse conditions. Again, we give the specific questions used in the table note. Finally, the organizers survey contains two variables that we regard as potentially good measures of the innate propensity of workplaces to vote for the union: the percentage of workers who signed authorization cards; and an index of "union propensity" created from questions regarding the attitudes of workers/community toward unionism and employer anti-union activity prior to the election, as listed in the table note. We use the card signing variable to test for the hypothesized nonlinearity in the impact of the innate probability of a union victory by forming two dumm variables to reflect the extremes of the distribution: the cases where 40 or fewer workers signed cards and the cases where more than 708 signed cards. The hypothesized nonlinearity should produce negatively signed coefficients on both dummy variables, distinguishing the extremes from cases with $40-708$ cards signed. We use the union propensity index to test for nonlinearity by entering linear and squared terms. Here nonlinearity should yield a negative squared term and positive linear term.

There are three findings in the table. First, our measures of positive industrial relations/potential profit loss from unionism have the expected inverse relation to management committing unfair practices or firing/laying off union activists: the greater the number of fringe benefits the less likely management is to commit unfair practices/fire or discriminatorily layoff union activists while by contrast the poorer work conditions/ supervisory practices the more likely they are țo commit such actions. 
Second, however, we find that while poor work conditions/supervisory practices increase the probability that supervisors campaign against the union, good benefit packages also increase the probability that supervisors campaign against the union, perhaps because this gives them a strong argument against the union. Third, we find some evidence for nonlinearity in the relation between our indicators of the innate probability to unionize and unfair practices. In columns 1 and 2 the nonlinearity shows up in our union propensity index, which takes a parabolic form so that a greater union propensity has first an increasing then a decreasing effect on management opposition. The percentage who sign cards, by contrast, does not evince such a reversal of effects: it shows a fairly continuous impact of cardsigning on unfair practices/firings/discriminatory layoffs, with greater proportions signing cards leading to lesser management opposition. This supports the notion that management will campaign less virulently when a union has strong support but not the notion that it also campaigns less when a union has weak support. In the column 3 calculations for the determinants of whether supervisors campaign against the union or not, however, the percentage who sign cards has the predicted nonlinear effect, with both high and low percentage cards reducing the probability a company will direct supervisors to campaign against the union. In the underlying data 868 of companies have supervisors campaigning against the union when there are 708 or more card-signers, 958 of companies have them campaigning against the union when 40-70z sign, and 848 have them campaigning when less than 408 have them sign. The union propensity index has no effect in this calculation, however. While each equation shows some indication of nonlinearity, the fact that different indicators show up differently between 
them suggests that this finding be vlewed with caution. The strong result is that firms faced with work forces with the greatest innata probability to rote union show less opposition to unions than others.

\section{Determinarits of outcomes}

While, as noted earlier, there are potential problems in astimating the determinants of NLRB representation election in a model in which opfosition is endogenous, we have stitrated logistic equations relating the probability that a union will win a representation election to measures of Fork conditions and opposition. Even though we are unlikely to obtain the "true" underlying structural relations of equation 1 . it is important to see whether our hypothesized indicators of the innate probability of a union wir: have a positive effect on winning with methods of opposition held fixed; whether any methods of opposition reduce that probability of a union win despite potential econometric problems that should bias estimates toward zero; and whether or not indicators of "positive industrial relations" have their expected effect on the chances of a union victory.

Table 5 presents the results of our analysis of the determinants of a union victory in the two surveys. The coefficients reported in column 1 show that our principal measure of management opposition in the employers survey--consultant days used--had a significant negative impact on the probability of a union win. The coefficient on the compensation difference variable is positive, and personnel practices are negative, as one would expect, but not significant, while the coefficient on unfair practices is positive with a standard error of approximately the same size. The coefficients reported in column 2 for the organizers survey give a similar picture of the determinants of outcomes, though with some differences in the 
impact of particular variables. Here, two factors stand out: the percentage of workers who sign cards has the greatest positive impact on a union victory while supervisory opposition has the greatest negative impact. The index of total benefits has the expected negative effect on the probability of a union win but its coefficient is not significant, in part because it is inversely related to the fraction who sign cards. The index of work conditions/supervisory practices also has an insignificant but correctly signed impact, for the same reason. Finally, in colum 3 we add a variable for which we have measures in only about haif of the cases--an index of the intensity of supervisory opposition (scaled from 1 to 5). With the mean entered for missing values and a dumy variable to flag those cases, we see that intensity of supervisor's opposition is a major determinant of outcomes. Finally, note that in the organizers survey unfair practices are positively rather than negatively related to the probability of a union victory. One likely reason for this seemingly aberrant result in both surveys is that unions are unlikely to file charges, even if illegal acts were comitced, if they win the election drive. There is, moreover, nothing inconsistent between these results and time series or industry/state calculations that find that the proportion of workers who are organized through NLRB elections is reduced by the frequency of unfair practices, as much of that variation in these stucies results from variation in the number of NLRB elections held rather than from variation in win rates. It does, however, underscore that unfair practices in aggregate studies should be viewed solely as an indicator of management opposition and that its impact is largely on the number of organizing campaigns. 12

\section{Effect of Organizing Drives on Management Careers}


How does a union organizing drive affect management? As most union studies are concerned with what unions do for their members, there is relatively little information on this question (see, however, Clark for intriguing evidence on a small sample of firms). An analysis of management opposition to organizing drives cannot, however, neglect the issue. From the perspective or our model it is important to delineate the direct incentives management, as opposed to stockholders, have to oppose unionism. Knowing how higher management/stockholders treated managers in firms facing drives is also important in evaluating their perceptions of the cause for the organizing campaign. Accordingly, we asked management what had happened to the plant managers in our employers survey--whether they were promoted, fired, sent for retraining or reassigned, or other. For the purposes of establishing a benchmark we asked the same question of 33 firms who do not experience an organizing drive: these firms were those named by the firms in our sample as their "closest competitor" (see Freeman and Kleiner, 1988). and we asked them for the distribution of career outcomes for establishment managers in the same period in which the organizing drive took place.

Table 6 tabulates the responses to this question, by the organizing status of the firm. Line 1 shows the distribution of changes in manager stacus for 202 establishments in our sample in which elections took place. Lines 2 through 4 give the distributions for varying outcomes of the organizing drive: a union win and a contract; a union win and no contract; and a union loss in the election. Line 5 gives the distribution for the "control" subsample of matched (nonunion) establishments that did not face an organizing drive, while line 6 shows the distribution for the pairs of these establishments. The results show a clear impact of both an organizing 


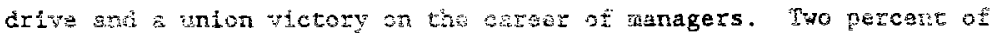

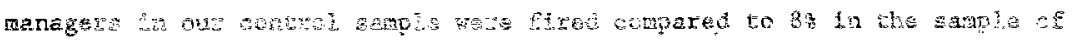
estats

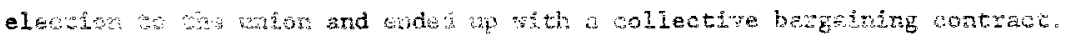

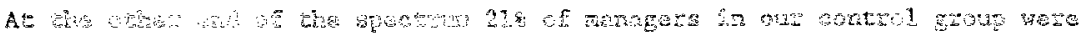

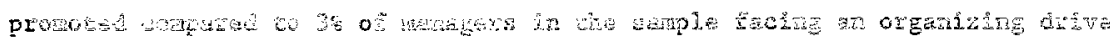

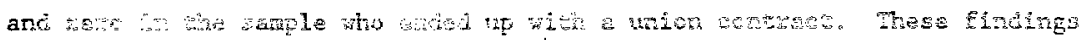

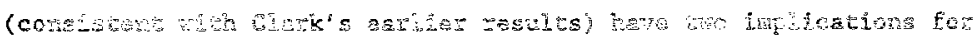

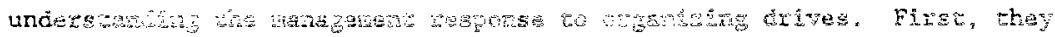
suggert

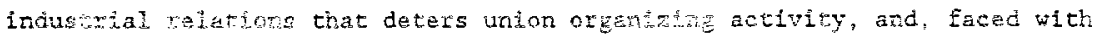
a crire, to angage in any activities that will defeat the union. Second, the rasuites an also be interpreted as inchersing that a union organizing drive sigrals stockiolders and top management that the establishment management is, in fact, poor, and should be replaced.

\section{Conclusions}

The direct role of employers in urion organizing has long been a neglected part of the union organizing literature. In this study we have examined the determinants and consequences of employer behavior when faced with an organizing drive. Our principal substantive findings are:

o that there is a substitution between high wages/benefits/good work conditions/supervisory practices and "tough" management opposition to unionism.

o that a high innate propensity for a union victory deters management opposition, while some indicators of a low propensity also reduce opposition. 
- that "positive industrial relations" raise the chances the firm will defeat the union in an election, as does bringing in consultants and having supervisors campaign intensely against the union.

o that the careers of managers whose wages/supervisory practices/benefits lead to union organizing drives, much less to union victories, suffer as a result.

In general we interpret our results as consistent with the notion that firms behave in a profit maximizing manner in opposing an organizing drive and with the basic proposition that management opposition, reflected in diverse forms of behavior, is a key component in the on-going decline in private sector unionism in the United States. 
TABLE 1: Percentage of AlL Finms Using Speciffed Method of Opposing Unton Organizing Drive

\section{A. EXPLOYER SURVEY}

Consultants Used (yes):

$<$ month

418

1 month or more

$13 \%$

$28 \&$

Unfair Labor Practices: Chazges filed

24 \&

Guilty

B, ORGANIZER SURVEY

Consultants/Lawyers Used (yes):

70 \&

Unfair Labor Practices:

Filed

$36 \&$

Discharges or Discriminatory layoffs

Tactics:

$$
\begin{aligned}
& \text { Company Leaflets } \\
& \leq 4 \\
& 5 \text { or more } \\
& \text { Company Letters } \\
& \leq 4 \\
& 5 \text { or more }
\end{aligned}
$$

80 \%

913

Captive Audience Speech

91 8

$$
\begin{array}{ll}
5 & 4 \\
5 & \text { or more }
\end{array}
$$

Supervisory Small Mtgs. per/employee

928

$$
\begin{aligned}
& \leq 4 \\
& 5-8 \\
& 9 \text { or more }
\end{aligned}
$$

Supervisor Intensity in opposing union ${ }^{1}$

Low

Moderate

Source: Employer Survey: NBER Survey of 203 Establishments that faced organizing drives.

Organizer Survey: AFL-CIO Department of Organization \& Field Services, Survey of 276 organizers.

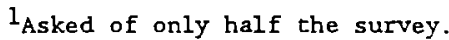


TABLE 2: Percefved Causes of Organizing Drtye and Issues in Drive

\section{A. EMPLOYER SURVEY}

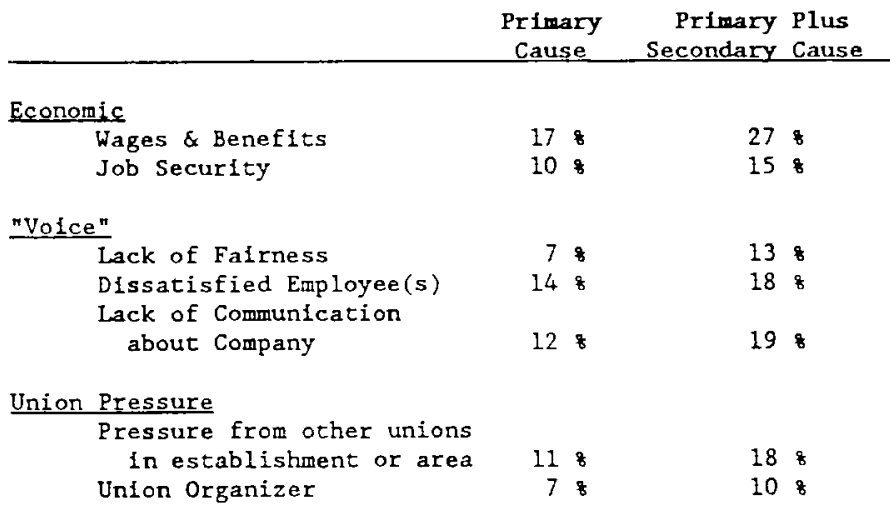

B, ORGANIZERS SURVEY

Most Important Issue

\begin{tabular}{lr} 
Beneficial for Union Issues & \\
\hline Supervisory & 528 \\
Wages & 278 \\
Fringes & $6 \%$ \\
Safety & 78 \\
Discrimination & 38 \\
Pressure & 58 \\
Beneficial for Management Issue & \\
\hline Strikes \& Closing & 368 \\
Layoffs \& & 168 \\
Dues & 158 \\
Wages & 28 \\
Other & 318
\end{tabular}

Source: See Table 1. 
TABLE 3: Coefficlents and Standard Errors of Hanagement Opposition: Enployer Survey

\begin{tabular}{|c|c|c|c|c|}
\hline & $\begin{array}{l}\text { Charge of } \\
\text { Unfair } \\
\text { Practice }\end{array}$ & $\begin{array}{l}\text { Guilty of } \\
\text { Unfair } \\
\text { Practice }\end{array}$ & $\begin{array}{c}\text { Hired } \\
\text { Consultant } \\
\end{array}$ & $\begin{array}{l}\text { Consul tant } \\
\text { Days Used }\end{array}$ \\
\hline \multicolumn{5}{|l|}{$\begin{array}{l}\text { Explanatory } \\
\text { Variable }\end{array}$} \\
\hline $\begin{array}{l}\text { Union Compensa- } \\
\text { tion Difference }\end{array}$ & $\begin{array}{l}2.50 \\
(1.50)\end{array}$ & $\begin{array}{l}3.47 \\
(1.74)\end{array}$ & $(1.30)$ & $\begin{array}{c}1.09 \\
(6.89)\end{array}$ \\
\hline $\begin{array}{l}\text { Index of Person- } \\
\text { nel Practice }\end{array}$ & $\begin{array}{l}-.21 \\
(.16)\end{array}$ & $\begin{array}{l}-.19 \\
(.16)\end{array}$ & $\begin{array}{l}.14 \\
(.12)\end{array}$ & $\begin{array}{l}.54 \\
(.56)\end{array}$ \\
\hline \multicolumn{5}{|l|}{ 0ther Controls } \\
\hline $\begin{array}{l}\text { Number of } \\
\text { Employees }\end{array}$ & $\checkmark$ & $\checkmark$ & $\checkmark$ & $\checkmark$ \\
\hline $\begin{array}{l}\text { Production/ } \\
\text { Non-Production }\end{array}$ & $\checkmark$ & $\checkmark$ & $\checkmark$ & $\checkmark$ \\
\hline $\mathrm{KC} /$ Boston & $\checkmark$ & $\checkmark$ & $\checkmark$ & $\sim$ \\
\hline Mfg/Other & $\checkmark$ & $\checkmark$ & $\checkmark$ & $\sim$ \\
\hline \multicolumn{5}{|l|}{$\begin{array}{l}\text { Dummies for } \\
\text { Missing Indepen- } \\
\text { dent Variables }\end{array}$} \\
\hline $\begin{array}{l}\text { Experience } \\
\text { with Union }\end{array}$ & $\checkmark$ & $\checkmark$ & $\checkmark$ & $\checkmark$ \\
\hline \multicolumn{5}{|c|}{ Sumary Statistics } \\
\hline Sample Size & 188 & 184 & 188 & 184 \\
\hline Technique & Logistic & Logistic & Logistic & Tobit \\
\hline-2 Log Likelihood & 184.0 & 142.3 & 239.5 & 682.85 \\
\hline
\end{tabular}

$1_{\text {Sum }}$ of whether firm had any of 5 practices:

1) Formal Written Grievance Procedure

2) Formal Written Seniority System for Promotions,

3) Formal Written Sick Leave Policy

4) Written Posting of Training Opportunities

5) Formal Written Policy for Layoff and Recalls 
TABLE 4: Coeffictents and Standard Errors for Deterpinants of Management Opposition: Organizer's Survey

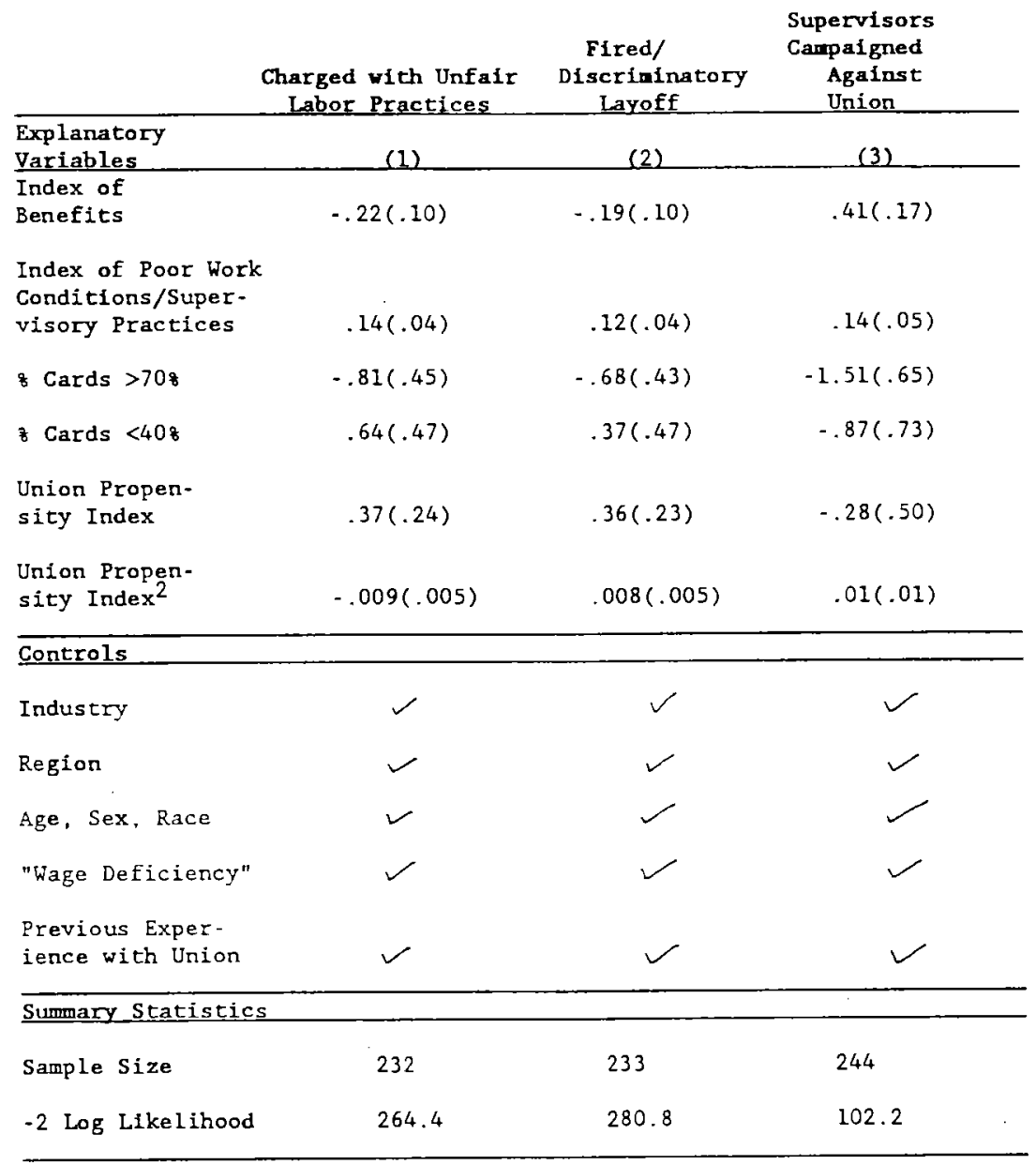




\section{NOTES TO TABLE 4}

Index of Benefits sums $0-1$ variables for medical insurance, dental insurance, sick pay, pension, grievance procedure, arbitration, employee handbook, open door policy, quality of work life.

Index of work conditions/supervisory practices sums answers to: Is supervision unpredictable, inconsistent or autocratic? Is the work of a routine nature where employees receive little recognition from supervisors or little personal job satisfaction? Are employees stuck in "dead-end" jobs with little chance for promotion? Have there been major accidents in the plant, or are there serious threats to the health and safety of workers? Are there severe pressures, including mandatory overtime, placed on employees to maintain or increase production? Is there evidence of discrimination or favoritism of any kind? Do the employees feel that the company has little personal concern for them?

Index of union propensity: sums answers to: Has the workplace been subjected to substantial anti-union propaganda and/or attitude surveys before the organizing campaign started? Does the company have a preemployment screening process to weed out potential union sympathizers? Do a substantial number of employees belong to civil rights groups, tenant associations, social advocacy groups or church organizations which are active in community affairs? Is there access to employees, either on or off the job? Are labor unions generally well accepted within the community? Have there been any recent shutdowns of large union plants or establishments in the community? Have there been bitter, highly publicized strikes in the community in the past few years? Is employee turnover relatively low?

The variables in the work practices/supervisory conditions and union propensity indices are scaled from 1 to 5 , as described in the text. 
TABLE 5: Coefficients and Standard Errors of the Determinants of Union Victory in NLRB Representation Election

\begin{tabular}{|c|c|c|c|}
\hline Union Compensation Difference & $1.91(1.34)$ & & \\
\hline Consultant Days Used & $-.04(.02)$ & & \\
\hline Index of Personnel Practices & $-.17(.12)$ & & \\
\hline Unfair Practices & $.53(.46)$ & $.81(.43)$ & $.72(.45)$ \\
\hline Index of Total Benefits & & $-.09(.10)$ & $-.07(.10)$ \\
\hline $\begin{array}{l}\text { Index of Work Conditions } \\
\text { Supervisory Practices }\end{array}$ & & $.03(.03)$ & $.05(.03)$ \\
\hline $\begin{array}{c}\text { Supervisors Campaign } \\
\text { Against Unions }\end{array}$ & & $-2.11(.67)$ & $-1.98(.72)$ \\
\hline Intensity of Supervisors* Campaign & & -- & $-.75(.20)$ \\
\hline \& Cards & & $4.52(1.05)$ & $4.89(1.09$ \\
\hline Index of Union Propensity & & $.06(.03)$ & $.04(.03)$ \\
\hline OTHER CONTROLS & A & $\mathrm{B}$ & $\mathrm{B}$ \\
\hline SUMMARY STATISTICS & & & \\
\hline$N$ & 190 & 240 & 240 \\
\hline - 2 Log Likelihood & 225.4 & 277.4 & 334.6 \\
\hline
\end{tabular}

Notes: A - See Table 3 controls.

$B$ - See Table 4 controls. Also with dumy Eor whether consultant/lawyer was used.

* Available for 124 campaigns only. 
TABLE 6: Percentage of Fins Changing Manager Status, by Organizing Defye

\begin{tabular}{|c|c|c|c|c|c|c|}
\hline $\begin{array}{c}\text { No } \\
\text { Change }\end{array}$ & $\begin{array}{l}\text { Manager } \\
\text { Pronoted }\end{array}$ & $\begin{array}{l}\text { Manager } \\
\text { Sent for } \\
\text { Retraining }\end{array}$ & $\begin{array}{l}\text { Manager Re- } \\
\text { assigned to } \\
\text { Another } \\
\text { Location }\end{array}$ & $\begin{array}{c}\text { Manager } \\
\text { Flred }\end{array}$ & other & No Answer \\
\hline
\end{tabular}

(1) All establish-

ments with or-

ganizing drives

(Percent) N-202

76

3

1

8

8

1

(2) Establishments

where the union

won and a con-

tract was

reached (Per-

cent) $\mathrm{N}=50$

82

0

2

2

10

2

(3) Establishments

where the union

won the elec-

tion, but no

contract was

reached (Percent)

61

7

0

4

18

4

(4) Establishments where the union

lost the election

(Fercent) $\mathrm{N}=124$

77

3

0

3

8

1

(5) Sub-sample of

firms without

union and no

election. $\mathrm{N}-33 *$

21

3

4

2

9

(6) Paired Sub-

sample of firms

[with those in (5)]

with organizing

drives. $\mathrm{N}=33$

70

0

3

15

6

6.1

Percentages sum to less than 100 due to rounding.

*These values are the means of the percentages of the change in manager status over the same time period as firms experiencing; an: organizing dive. 


\section{ENDNOTES}

1. As late as 1976 business leaders percelved labor as an overly powerful influence group and wanted strongly to reduce the power of labor. See Sydney Verba and Gary Orren, Equality in America (Harvard 1985).

2. Several studies have suggested that a major reason for the increased hostllity toward unions over this period was the growth in the unionnonunion wage gap, deregulation, and foreign competition with little change in union workers productivity relative to nonunion workers, resulting in reduced flrm profits (Freeman and Kleiner, 1986).

3. The unfair practices data are from NLRB. The percencage who get contracts is from Cooke (1985), McDonald (1983), and Freeman and Kleiner (1986).

4. A composite ranking of private sector union density in the states in our sample was 29 th out of 51 (D.C. included). The states in our sample that had NLRB election data included Arkansas, Connecticut, Iowa, Kansas, Maine, Massachusetts, Missouri, Nebraska, New Hampshire, and Vermont.

5. The AFL-CIO questionnaire contained information that differentiates between lawyers and consultants but that information was not coded and placed on the computer file that we used.

6. The problem is that the AFL-CIO questionnaire contained a question on firings and a separate question on "other unfair labor practices" that were filed with the NLRB. In the table we assume that firings were filed charges, but the questionnaire is ambiguous on this.

7. The questionnaire asked for a rating of intensity from 1 to 5 . Our high category is the 5 category, moderate is the 3 and 4 category and low is 1 and 2 .

8. Note that the surveys asked for somewhat different information. The employers survey asked for the causes of the election drive while the organizers survey asked for the most important issue in the campaign.

9. This finding is not inconsistent with Kleiner's results showing that current profitability is unrelated to committing an unfair practice. In the model we investigate it is the potential effect of unions on future profits that is the key determinant of unfair practices, not current profitability.

10. We regressed the difference in the $\log$ of wages one year after the NLRB election and one year before the election on the wage difference and a dunny variable for whether or not the firm signed a collective contract. The coefficient on the compensation difference variable was .09 with a standard error of (.04) while the coefficient on the collective bargaining durny was .01 with a standard error of (.01).

11. There was a question about whether the firm has a "wage deficiency" which we entered in the regression; it had the expected sign in the regressions but was of negligible statistical importance. 
12. Such a relation is to be expected if management opposition reduces the chances of union victories, leading unlons to be more selective in the campaigns they pursue. 


\section{BIBLIOGRAPHY}

Ashenfelter, Orley and G. E. Johnson, 1969, "Bargaining Theory, Trade Unions, and Industrial Strike Activity," Amerfcan Economic Review, Vol. 59, pp. $35-42$.

Clark, Kim B., 1984, "Unionization and F1rm Performance: The Impact on Profits, Growth, and Productivity," American Economic Review, pp. $893-919$.

Cooke, William, N., 1985, "The Failure to Negotiate First Contracts: Determinants and Policy Implications," Industrial and Labor Relations Review, January Vol. 38, No. 2, pp. 163-178.

Dickens, William T., 1983, "The Effect of Company Campaigns on Certification Elections: Law and Reality Once Again, "Industrial and Labor Relations Review, Vol. 36, No. 4, pp. 560-575.

Dickens, William T., and Jonathan S. Leonard, 1985, "Accounting for the Decline in Union Membership, 1950-1980." Industrial and Labor Relations Review, Vol, 38 , No. 3, pp. 323-334.

Farber, Henry S., 1987. "The Recent Decline of Unionization in the United States," Science, Vol. 238, pp. 915-920.

Freeman, Richard B., 1988, "Contraction and Expansion: The Divergence of Private Sector and Public Sector Unionism in the U.S.," Journal of Economic Perspectives, Spring.

Freeman, Richard B. and Morris M. Kleiner, 1988, "The Impact of New Unionization on Wages and Working Conditions: A Longitudinal Study of Establishments Under NLRB Elections, Journal of Labor Economics, forthcoming. 
Freman, Richard B., and Morris M. Kleiner, 1986, "Union Organizing Drive Outcomes From NLRB Elections During a Period of Economic Concessions," Industrial Relations Research Association, Vol. 39, pp. 41-47.

Freeman, Richard B., and James Medoff, 1984, What Do Unions Do?, New York: Basic Books, Inc.

Kleiner, Morris, M., 1984, "Unionism and Employer Discrimination: Analysis of 8(a)(3) Violations," Industrial Relations, Vol. 23, No. 2, PP. $234-243$.

Kochan, Thomas. A, Robert B. McKersie, and John Chalyhoff, 1986, "The Effects of Corporate Strategy and Workplace Innovations on Union Representation," Industrial and Labor Relations Review, Vol. 39, No. 4 pp. 487-501.

Little, Roderick J. A., and Donald Rubin, 1987, Statistical Analysis With Missing Data, New York: John Wiley \& Sons, pp. 6.9.

McDonald, Charles, 1983, "Memorandum to the National Organizing Commitcee," AFL-CIO.

Medoff, James, 1984, "The Public's Image of Unions," Bureau of National AfEairs, pp. D-1.

Pruitt, Stephen W., John Wei, and Richard White, 1988, "The Impact of UnionSponsored Boycotts on the Stock Prices of Target Fims," Journal of Labor Research, Summer, Vol. 9, No. 3, pp. 285-290.

Stephan, Paula E. and Bruce E. Kaufman, 1986, "Factors Leading to a Decline in Union Win Rates: 1973-1981," Industrial Relations Research Association, Vol. 39, pp. 296-305.

Verba, Sidney and Gary Orren, 1985, Equality in America: A View From the Top, Cambridge, MA: Harvard University Press. 